\title{
The Impact of Sustainability Practices on Stock Return: The Relationship Between Firm Value, CSR Disclosure, Firm Size and Profitability Evidence from Indonesia Publics Firms Listed on (SRI)-KEHATI Index
}

\author{
Triasesiarta Nur \\ \{triasesiarta.nur@binus.ac.id\} \\ Accounting Department, Faculty of Economics and Communication Bina Nusantara University
}

\begin{abstract}
Corporate Social Responsibility (CSR) projects of companies demonstrate the values and models of corporate governance and emphasize the relationship between business strategy and commitment to a sustainable global economy. Through CSR activities, companies can communicate sustainability performance that ultimately has an impact on its value. This study examines the relationship between CSR disclosure and firm value in Indonesia. The sample consists of Indonesian listed companies listed on (SRI)-KEHATI Index, period 2016-2019. Using multiple regression on the list of CSR disclosure, this study showed that CSR had no significant effect on the value of the firm. Nevertheless, it has been shown that the size of the companies significantly strengthens the effect of CSR on the firm value. In more detail, the size of the company also significantly moderates the dimensions of CSR disclosure. Although profitability does not moderate the effect of CSR on the firm value, including all components of CSR
\end{abstract}

Keywords: Business Sustainability, Firm Value, Corporate Social Responsibility, Profitability, Firm Size 


\section{Introduction}

The concept of CSR arises when awareness of the long-term sustainability of the company is more important than profitability. In essence, corporate social responsibility disclosure is intended to show the public about the company's social activities and their impact on the community. Corporate social responsibility (CSR) is proof that the company focuses not only on the interests of shareholders in the conduct of its business activities but also on the interests of stakeholders. Corporate social responsibility is a phenomenon of the corporate strategy that meets the needs and interests of stakeholders. Stakeholders, therefore, need information about CSR, which is obtained from annual accounts. [1].

In addition to the ability to sell products, an important part of the business strategy for any government is the ability to sell its shares ethically. At present, stakeholders increasingly expect companies to behave ethically and investors are more interested in companies that perform corporate social responsibility (CSR). Implementation of CSR can offer companies opportunities to increase the value of the firm [2]. The company benefits from its decision to take social responsibility. The company made this decision to gain recognition in the form of increased consumer demand for both the company's products and stocks and high employee productivity. This competitive advantage allows them to improve their financial performance [3]. Previous studies have shown that business value is related to the social responsibility it has applied by companies [4], [5][6], [7]. Negative effects on the environment often arise when a company carries out production activities to make a profit. The phenomenon of the emergence of CSR is expected to remind the company to pay attention to the environment. The concept of CSR arises when the long-term sustainable awareness of a company is more important than the benefits it gets [8]. The company's goal to disclose CSR is to show the public what the company has done related to social activities and their effect on business continuity. So that CSR becomes an important issue to be considered by investors.

Companies use CSR disclosure as a means to differentiate their companies from others. With the growing importance of sustainability management, companies are beginning to realize the importance of CSR as a business strategy tool. On the other hand, investors are increasingly aware of the increasing importance of investing in companies that carry out social responsibility, especially in companies with optimal CSR performance. CSR disclosures are increasingly becoming an important component of modern corporate culture because of the increasing expectations of 
stakeholders given the growing global awareness of the need for strong corporate governance, environmental protection, and social care. CSR can help businesses achieve social justice and economic prosperity by creating prosperity for various social groups, expanding their reach outside the company and their shareholders. This view is proven by several studies both inside and outside the country that show that CSR disclosure has a positive influence on firm value [9], [10]. However, several other studies show that CSR has a negative impact [11],[12] or does not affect the value of the company, [13] [14], [15].

Inconsistent research results regarding the effect of CSR on firm value open up opportunities to consider other factors as a moderating factor to explain the mechanism of the impact of CSR disclosure on firm value. CSR activities will have a positive impact on improving reputation and social community, but on the other hand, CSR will also cause a decrease in short-term profitability and conflict between social goals and financial goals. This has become a negative impact of CSR activities on the value of the firms [16]. Companies need significant funds to be socially responsible. In some companies this cost will cause financial performance to decline; so that only profitable companies can perform CSR activities [5]. In addition to profitability, a variable also considered that can explain the relationship between CSR disclosure and firm value is firm size. Total assets which are the size of the company are a reflection of the company's wealth,[17],[9]. Large companies tend to disclose more information about their environmental practices [18], [19], besides large companies are often considered more efficient and have enough resources to support the implementation of CSR programs.

There is not much research that then tries to focus on how CSR indicators affect firm value. Several studies have begun to focus on how CSR parameters affect both company performance and value,[19] on workforce behavior; [20] on consumer behavior; [21] linking firm values with four sub-indices of CSR, namely: social involvement, employees, products and services as well as environmental protection, while [22] and [23] analyze the influence of 6 CSR dimensions namely health, justice, social, consumer, environment and employee against firm value.

In recent years, the Government of Indonesia, through the Financial Services Authority, has promoted the importance of companies to comply with CSR and ensure transparency in the disclosure of good corporate governance. The Sustainable and Responsible Investment (SRI) - KEHATI stock index is an index indicative of the price movements of the Indonesia Stock Exchange (IDX). This index uses the principles of sustainability, finance, and good governance, as well as 
environmental management, as a benchmark. The index, launched by the Indonesian Biodiversity Foundation (KEHATI) in conjunction with PT BEI (Indonesia Stock Exchange), can be a benchmark for investors or investment managers in determining which public companies are performing well in doing business on financial, social, and environmental management in a sustainable way. Companies listed on the (SRI) - KEHATI Index are companies that are environmentally conscious, socially aware, and have good corporate governance. Investors therefore not only invest in the shares of the company but invest in the (SRI) - KEHATI index while preserving the environment of the company. CSR disclosures by companies in the (SRI) - KEHATI index will further expand the disclosure in the annual report. The more extensive disclosure by the company will contribute to the information received by investors. To increase investor confidence in the company, investors will naturally give a positive response to the company.

The aim and contribution of this research are to examine the relationship between CSR disclosure, profitability, size, and firm value; how profitability and company size affect firm value and CSR disclosure; and how the moderating role of profitability and company size influence the impact of CSR on firm value. This research also examines how the indicators of CSR, namely: environment, energy, health and safety of work, labor, products and community involvement influence firm value, how the moderating role of profitability and size influence the impact of CSR on firm value.

\section{Theoretical Framework}

\subsection{Theoretical Perspective on CSR}

\subsubsection{Agency Theory}

Agency theory underlies the differences in interests between principals and agents. This agency theory bases the contractual relationship between shareholders and management [24]. Corporations increase corporate social voluntary disclosure to avoid potential pressure from government legal entities that impose social responsibility. Voluntary disclosure can be used to reduce the problem of information asymmetry[24].

\subsubsection{Legitimacy theory}

Organizations are constantly striving to ensure that they carry out activities within the boundaries and standards of the communities in which they are located. 
The company has a contract with the community to conduct its activities based on the values that are in the community and how the company responds to various interest groups to legitimize the interests of the company. If there is any inconsistency between the company's value system and the community's value system, the company may lose its legitimacy, which in turn may compromise the company's sustainability [25].

\subsubsection{Stakeholder theory}

The company is not an entity that operates only for its interests but should provide benefits to its stakeholders (shareholders, creditors, consumers, suppliers, government, communities and other parties). Companies that operate need help from outside parties and one of them is community support. The management of an organization should carry out activities that are considered important by its stakeholders and then report to the stakeholders. This theory states that all stakeholders have the right to obtain information about how the activities of the organization play a role in the environment. Corporate sustainability depends on stakeholder support [26].

\subsection{CSR and Firm Value.}

CSR disclosure is the process of communicating the social and environmental impacts of the economic activities of society as a whole [27] Investors will value companies that disclose CSR more than those that don't. This has a positive impact on the company. Stakeholder theory requires that companies offer benefits to external parties. Companies can do this, among other things, by fulfilling their social responsibilities. Social responsibility is one of the rules and contracts that the company must adhere to. The contract was made by the company together with the community before the company was founded. This is in line with the theory of legitimacy, whereby companies must comply with the rules and standards that apply in the community to receive full support for the business activities. By implementing and implementing empowerment of social responsibility, it is expected to attract the attention of investors. This is consistent with signal theory.

Corporate social responsibility (CSR) practices conducted by companies have a positive relationship with the company's performance [28],[29]. If the company has a social responsibility, the employee will also be indirectly mentally positive towards the company. Companies that perform social responsibility will increase staff efficiency and productivity [30]. The more CSR activities revealed by the 
company, the value of the company will increase as the market will give a positive appreciation to companies doing CSR. Seen through customer relationships, customers will have more confidence in products from companies that have a clear identity by linking the company to its operations. So that it will have an impact on the company's performance.

H1: CSR disclosure has a significant effect on firm value

\subsection{Company size, CSR, and Firm value}

Larger size companies will be better able to influence products and larger markets, ultimately improving business performance. The size of the firm therefore has a positive impact on financial performance. By increasing company size, companies will have easier access to the capital market in obtaining financing, where the funds can be used by management to increase the value of the company. Larger size companies will be better to influence products and larger markets, improving business performance. The size of the company will influence management decisions when deciding which financing and investment decisions will be used by the company so that both financing decisions and investment decisions optimize business value. Company size has a positive impact on financial performance [31].

Nevertheless, some studies show the opposite that company size can have a negative or no significant effect on firm value [32],[33]. Company size does not guarantee that the company will have a high value. The companies may not be able to convince investors that management has the ability to manage corporate assets [34]. However, as the size of the companies grows, the company tends to get more public attention, putting more pressure on the public to carry out its social responsibilities. In a company that is growing, its reputation and history in the field of CSR will become more and more attached, making it difficult for the company to change/reduce CSR programs implemented so far. Empirical studies show that company size is positively related to CSR disclosure, If the size of the company influences both the firm value and the disclosure of CSR, then, the effect of CSR disclosure will be stronger on larger companies [17].

H2: Firm size has a significant effect on firm value

H3: Firm Size has a significant effect on CSR disclosure

H4: Firm size moderates the effect of CSR on firm value. 


\subsection{Profitability, CSR, and Firm Value}

Return on assets shows the effectiveness of management in generating revenue. This ratio also shows how companies manage their assets. The higher a company's ROA, the better its position in asset utilization. With a high return, investors can expect dividends yield because in a conventional economy, the motive of the investment is to achieve high gains, which will also increase investor interest to invest in companies shares so these ratio will have an impact on stock prices [34], [35].

The higher profitability make the CSR activities more widely known. The Company's performance and strategy to maintain stakeholder confidence may also impact the Company's viability. The broader the level of information, the more stakeholders believe in the sustainability of the company in the future. This confidence is reflected in how customers accepts firm products in the community. With these achievements, investors will look positively at the company, which will also increase the value of the firm by adding investor investments. CSR programs run by the company increase the value of the company as corporate profits rise [36], Companies with high profitability are given more opportunities to implement CSR programs. So the higher the profitability, the more likely companies are to make CSR disclosures. The more CSR activities are announced, the value of the company will also increase, especially among companies with high profitability. For companies with higher profits, the relationship of CSR with firm value will be stronger [37], [38].

H5: Profitability has a significant effect on firm value

H6: Profitability has a significant effect on CSR disclosure

H7: Profitability significantly moderates the effect of CSR on firm value

\section{Methodology}

3.1. Sample and data collection

To test the hypothesis, this study uses a sample of companies whose shares are listed on the (SRI)-KEHATI Index, one of the indices on the Indonesia Stock Exchange in the period 2016-2019, with a total of 90 observations.. The method for determining the sample in this study is the method of purposive sampling, ie the sample is determined with certain considerations following criteria. The criteria used as the basis for determining the sample in this study are Companies listed on 
the (SRI)-KEHATI index that was listed on the Indonesia Stock Exchange for the period 2016-2019.

(SRI)-KEHATI Index is an equity index of sustainable and responsible investment (SRI) that is the result of a collaboration between the Indonesian Biodiversity Foundation (KEHATI) and the Indonesia Stock Exchange. The principle of (SRI)-KEHATI Index is in line with international agreements that are realized in the form of Sustainability Stock Exchange (SSE). The SSE initiative is an agreement that the stock market index should not only look at financial aspects. Moreover, other aspects such as environment, social and governance should also be part of the regulatory framework for the exchange.

\subsection{Research variables}

\subsubsection{Dependent variable}

Firm value

The company aims to achieve high business value and sustainable growth. The growth of the company is reflected in the high valuation of the company's assets and market prices. The value of the company is reflected in the share price. The firm value does not depend on the ability to generate cash flow but also depends on the operational and financial characteristics of the company. Price to Book Value (PBV) is an indicator for determining the value of a company. PBV explains how many investors examine the book value of a company's equity. PBV is the ratio between share price/market value and book value. PBV shows how much the company can create business value with the invested capital, so a higher PBV ratio indicates that the company has succeeded in creating value for shareholders.

\subsubsection{Independent variable}

Corporate social responsibility (CSR)

The CSR disclosure category uses GRI (Global Reporting Initiative) standards that consist of 3 disclosure focuses, economic, environmental, and social, as the basis for sustainability reporting. The GRI contains several indicators, namely: financial performance indicators, environmental performance indicators, labor performance indicators, human rights performance indicators, social performance indicators and product performance indicators. GRI is the most widely used sustainability reporting framework in the world to promote greater transparency. 
Within these indicators, there are 79 categories (environment consists of 13 indicators, energy consists of 7 indicators, health and safety of personnel consist of 8 indicators, personnel consists of 29 indicators, products consist of 10 indicators and community involvement from 11 indicators). Each category contains specific details of the disclosure area and is marked with code 0 or 1 . A value of 0 is given if no information is disclosed [39]. And a value of 1 is given if the company has performed multiple activities in accordance with the coded category. Then the score of each item is added together to get the overall score for each company. Each company's disclosure index is then calculated by dividing the number of items disclosed by the company by the number of items the company expects, which is equivalent to previously conducted research in Indonesia using the following formula:

$$
\operatorname{CSR}=\frac{V}{M}
$$

CSR: CSR disclosure index

Q: Number of items published by the company

M: number of items to be disclosed

Profitability

This research use Return on Asset for profitability measurement.

\section{Firm Size}

The size of company in this research is measured by natural logarithm of total assets.

Table 1.Operational Variables Measurement

\begin{tabular}{ll}
\hline Variables & Definition \\
\hline PBV & Price to Book Value \\
Firm Size & Logarithms Natural of Total Assets \\
Profitability & Net income to total assets \\
CSR & Based on CSR indicators, which consist of 78 indicators. The \\
& number of items to be disclosed by the company is divided by \\
& the number of items to be disclosed \\
CSR Parameter : & $\begin{array}{l}\text { The environment (Env) consists of 13 indicators, energy } \\
(\text { energy)consists of } 7 \text { indicators, health and safety of personnel } \\
(H \& S) \text { consist of } 8 \text { indicators, labor (labor) consists of } 29\end{array}$ \\
\hline
\end{tabular}


indicators, products (products) consist of 10 indicators and community involvement $(C I)$ consists of 11 indicators.

The number of items published by the company is divided by the number of each indicator to be published.

Sources: Author

\subsection{Model Specification}

Model 1: The impact of CSR on Firm Value

$P B V_{i}=\alpha_{i}+\beta_{1} \operatorname{CSR}_{i}+\beta_{2} R_{O A A_{i}}+\beta_{3} \operatorname{SIZE}_{i}+\varepsilon_{I}$

Model 2: The impact of ROA and SIZE on CSR

$\operatorname{CSR}_{i}=\alpha_{i}++\beta_{1} R O A_{i}+\beta_{2} \operatorname{SIZE}_{i}+\varepsilon_{I}$

Model 3: ROA moderates the effect of CSR on Firm Value

$P B V_{i}=\alpha_{i}+\beta_{1} C S R_{i}+\beta_{2} R O A_{i}+\beta_{3} \operatorname{SIZE}_{i}+\beta_{4} R O A_{i} * C S R_{i}+$

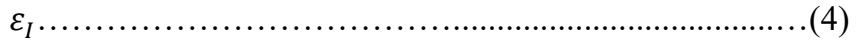

Model 4: Firm Size moderates the effect of CSR on Firm Value

$P B V_{i}=\alpha_{i}+\beta_{1} C S R_{i}+\beta_{2} R O A_{i}+\beta_{3} \operatorname{SIZE}_{i}+\beta_{4} \operatorname{SIZE}_{i} * \operatorname{CSR}_{i}+\varepsilon_{I}$

\section{Additional Models}

Model 5: The impact of CSR's parameter on Firm Value $P B V_{i}=\alpha_{i}+\beta_{1}-\beta_{5}$ Parameter $\operatorname{CSR}_{i}+\beta_{6} R O A_{i}+\beta_{7} S_{I Z E_{i}}+\varepsilon_{I}$

................................................(6)

Model 6: ROA moderates the effect of CSR's Parameter on Firm value $P B V_{i}=\alpha_{i}+\beta_{1}-\beta_{5}$ Parameter $\operatorname{CSR}_{i}+\beta_{6}-\beta_{10} R O A *$ Parameter $\operatorname{CSR}_{i}+\varepsilon_{I}$

...................................(7)

Model 7: Firm Size moderates the effect of CSR's Parameter on firm value $P B V_{i}=\alpha_{i}+\beta_{1}-\beta_{5}$ Parameter $\operatorname{CSR}_{i}+\beta_{6}-\beta_{10}$ SIZE $*$ Parameter $\operatorname{CSR}_{i}+\varepsilon_{I}$

\section{Results and Discussion}


Descriptive statistics are shown in Table 2. Table 3 shows the results of multiple regression for testing hypotheses 1 to 7, namely: To see how CSR, ROA and firm size influence value of the firm, how ROA and firm size influence CSR, and how the moderating role of ROA and firm size impact the influence of CSR on value of the firm. Model 1 shows that CSR disclosure has no significant effect on firm value, so the data does not support hypothesis 1 . Firm value can be explained by both SIZE and ROA which are statistically significant so that the data supports $\mathrm{H} 2$ and H5. Model 2 shows that profitability has no significant influence on the disclosure of CSR, H6 is not supported by data. While the size of the company is statistically significant affects the company's CSR disclosure, H3 is accepted. The results show in model 3 that profitability does not statistically moderate the effect of CSR on the value of the firm, H4 is not supported by data; while model 4 prove that the company size plays a role in enhancing the influence of CSR on the firm value, $\mathrm{H} 4$ supported by data.

Model 5, 6, and 7 are additional analyses in which an examination of CSR indicators is carried out. The results show consistency between Model 5, 6 and Model 1. The same as in Model 1, model 5 shows that all CSR components also not significantly affect the firm value. In model 6 , profitability has no moderating role on the impact of the CSR component on the value of the firm. Nevertheless, model 7 shows that company size reinforces the influence of most CSR components on firm value.

Both model 1 and model 5 prove that CSR and its indicators do not significantly influence firm value. The samples are companies listed on the sustainable and responsible investment stock index (SRI) -KEHATI Index. These companies are already companies that use the principles of sustainability, financial and good governance, as well as environmental considerations as a benchmark. Investors have realized that these companies have CSR programs, so a disclosure no longer has a significant impact on the value of the company. The value of the firm is determined more by both profitability and size. Although profitability is statistically significant in determining the firm value, Model 2 shows that profitability has no moderating role on the influence of CSR disclosure on firm value, as seen in both Model 3 and Model 6. The size of the company's profitability does not guarantee that the company will provide sufficient funds to implements its CSR programs [40], [41].

The profits-altruism debate states that CSR is a corporate cost and thus decreases a firm's capability to preserve a high level of profitability whereas a 
company's involvement in its profit making leads to ordinary resolution of social unpleasantness. This study result shows that profitability does not significantly influence value of the firm nor moderate the impact of CSR on firm value. Firm value is represented by its share price or simply the present value of expected future cash flows. In this framework, CSR programs generate shareholder wealth if they enhance future cash flows (profits) or decrease the risk of those cash flows.

CSR activities can straight increase financial performance by decreasing costs, improving revenues or lowering risks. The simplest means to enhance profit is to decrease expenses/costs. Firms for example can convert to cleaner and cheaper energy alternatives. CSR activities aim to improve revenue. Companies can raise their revenue by selling more or selling at a higher price. Customers are willing to pay a premium for socially responsible products for many motives. For example, they have confidence that those products are superior compare to other non socially responsible substitutes. Even if CSR activities require new investment of some extra expense, a risk decrease can create shareholder value. Firm CSR activities facilitate the company to legally avoid taxes or charges; all of which decrease firm cash flow. The essential thing for companies is not merely to acquire profit but how to generate shareholder value. CSR program implementations need high investment. Profit is not sufficient to support those CSR activities, Companies have to make sure the revenue premium offsets any additional expenses from CSR programs.

Model 1 shows that company size significantly influences firm value, while model 2 proves that company size significantly moderates the influences of disclosure of CSR on firm value, thus consistent with method 7, company size moderates the influence of CSR's indicators on firm value. For large companies, the influence of both CSR and the indicators on the business value is stronger. There are several reasons indicate that the company size influences the relationship between CSR and firm value. Large companies usually have more assets and resources compare to smaller ones [40]. With More Limited funds, smaller companies will try to improve company performance, not by CSR program but more in traditional ways, while bigger companies have more flexibility to invest in CSR Projects, including effectively establishing relationships with its stakeholders to maintain business continuity. Besides, a CSR project requires a large-scale complex process to be effective and successful [42]. The characteristics of large companies are they have all the resources, allocation procedures and many people to facilitate CSR projects. In addition, if they are related to the life cycle of the 
company, large-scale companies that have reached the maturity stage usually no longer have attractive investment opportunities, making them more flexible to allocate the fund for CSR interests [41]. Large companies also have a greater chance of realizing CSR projects because they have stronger goals and more systematic procedures to monitor their activities.

\section{Conclusion}

This research aims to examine the relationship between CSR disclosure, profitability, size, and firm value; how profitability and company size affect firm value and CSR disclosure; and how the moderating role of profitability and company size influence the impact of CSR on firm value. This research also examines how the indicators of CSR, namely: environment, energy, health and safety of work, labor, products and community involvement influence firm value, how the moderating role of profitability and size influence the impact of CSR disclosure on firm value. The results show that CSR disclosure has no significant effect on firm value; Size and profitability statistically significant influence firm value; profitability does not influence CSR disclosure, while size statistically significant influence CSR disclosure. Size positively significant moderates the impact of CSR disclosure on firm value, while profit does not has moderating role on CSR disclosure and firm value relationship. The results also consistent with CSR indicators. All CSR indicators do not influence firm value. Size has moderating role on CSR parameters' influence on firm value. However, the same is not the case for profitability. Profitability does not have a moderating role in the relationship between CSR indicators and firm value. 
Table 2. Descriptive Statistics

\begin{tabular}{llrrr}
\hline \multicolumn{1}{c}{ Variable } & \multicolumn{1}{c}{ Minimum } & \multicolumn{1}{c}{ Maximum } & \multicolumn{1}{c}{ Mean } & \multicolumn{1}{c}{ Std. Deviation } \\
\hline PBV & 0.378328224 & 3.716845642 & 1.768549781 & 0.731358907 \\
CSR & .2025316455 & .873417721 & .545288326 & .143239503 \\
Size & 12.98000000 & 20.270000000 & 17.186333333 & 1.472540760 \\
ROA & .6000000000 & 39.900000000 & 11.766555555 & 10.200738810 \\
Env. & .0000000000 & .253164556 & .101126721 & .063361269 \\
Energy & .0000000000 & .075949367 & .024050632 & .018885137 \\
Prod & .0253164556 & .215189873 & .112095639 & .045995932 \\
Masy & .0632911392 & .291139240 & .142194092 & .045819020 \\
K3 & .0000000000 & .101265822 & .036427566 & .024728471 \\
General & .0000000000 & .095922365 & .045267329 & .016898852 \\
\hline
\end{tabular}

Table 3. Regression Result

\begin{tabular}{|c|c|c|c|c|c|c|c|}
\hline items & Model 1 & Model 2 & Model 3 & Model 4 & Model 5 & Model 6 & Model 7 \\
\hline Dep Vble & PBV & CSR & PBV & PBV & PBV & PBV & PBV \\
\hline Intercept & $\begin{array}{l}1.406885 \\
(0.0000)^{* * *}\end{array}$ & $\begin{array}{l}86.3256 \\
(0.0000)^{* * *}\end{array}$ & $\begin{array}{l}8.797330 \\
(0.0000)^{* * *}\end{array}$ & $\begin{array}{l}22.81118 \\
(0.0079)^{* * *}\end{array}$ & $\begin{array}{l}1.844825 \\
(0.4950)\end{array}$ & $\begin{array}{l}0.804762 \\
(0.7427)\end{array}$ & $\begin{array}{l}29.69893 \\
(0.0001)^{* * *}\end{array}$ \\
\hline CSR & 0.007088 & & $\begin{array}{l}0.023379 \\
(0.1245)\end{array}$ & $\begin{array}{l}0.398502 \\
(0.0317)^{* *}\end{array}$ & & & \\
\hline ROA & $\begin{array}{l}0.077891 \\
(0.0000)^{* * *}\end{array}$ & $\begin{array}{l}0.020660 \\
(0.8587)\end{array}$ & $\begin{array}{l}0.036999 \\
(0.4707)\end{array}$ & & $\begin{array}{l}0.070466 \\
(0.0000)\end{array}$ & $\begin{array}{l}0.137000 \\
(0.0188)^{* *}\end{array}$ & \\
\hline SIZE & $\begin{array}{l}0.372147 \\
(0.0007)^{* * *}\end{array}$ & $\begin{array}{l}2.530066 \\
(0.0029)^{* * *}\end{array}$ & & $\begin{array}{l}0.829132 \\
(0.0814)^{*}\end{array}$ & $\begin{array}{l}0.373338 \\
(0.0100)^{* *}\end{array}$ & $\begin{array}{l}0.373250 \\
(0.0038)^{* * *}\end{array}$ & \\
\hline CSR*ROA & & & $\begin{array}{l}0.000356 \\
(0.7522)\end{array}$ & & & & \\
\hline CSR*SIZE & & & & $\begin{array}{l}0.023163 \\
(0.0283)^{* *}\end{array}$ & & & \\
\hline Env & & & & & $\begin{array}{l}0.016002 \\
(0.6491)\end{array}$ & & $\begin{array}{l}0.426712 \\
(0.3401)\end{array}$ \\
\hline Energy & & & & & $\begin{array}{l}0.053283 \\
(0.5532)\end{array}$ & $\begin{array}{l}0.083815 \\
(0.4624)\end{array}$ & $\begin{array}{l}3.594646 \\
(0.0004)^{* * *}\end{array}$ \\
\hline Prod & & & & & $\begin{array}{l}0.033090 \\
(0.2918)\end{array}$ & $\begin{array}{l}0.027695 \\
(0.5092)\end{array}$ & $\begin{array}{l}1.472372 \\
(0.0021)^{* * *}\end{array}$ \\
\hline Com & & & & & $\begin{array}{l}0.030283 \\
(0.2452)\end{array}$ & $\begin{array}{l}0.024708 \\
(0.4486)\end{array}$ & $\begin{array}{l}0.713553 \\
(0.0175)^{* *}\end{array}$ \\
\hline K3 & & & & & $\begin{array}{l}0.114206 \\
(0.1156)\end{array}$ & $\begin{array}{l}0.010797 \\
(0.9006)\end{array}$ & $\begin{array}{l}3.037292 \\
(0.0054)\end{array}$ \\
\hline Env*ROA & & & & & & $\begin{array}{l}0.000723 \\
(0.8775)\end{array}$ & \\
\hline Energy*ROA & & & & & & $\begin{array}{l}0.008670 \\
(0.3279)\end{array}$ & \\
\hline Prod*ROA & & & & & & $\begin{array}{l}0.004134 \\
(0.4781)\end{array}$ & \\
\hline Com*ROA & & & & & & $\begin{array}{l}0.005446 \\
(0.2597)\end{array}$ & \\
\hline $\mathrm{K} 3 * \mathrm{ROA}$ & & & & & & $\begin{array}{l}0.009410 \\
(0.2711)\end{array}$ & \\
\hline Env*SIZE & & & & & & & $\begin{array}{l}0.024046 \\
(0.3527)\end{array}$ \\
\hline Energy*SIZE & & & & & & & $\begin{array}{l}0.207349 \\
(0.0004)^{* * *}\end{array}$ \\
\hline Prod*SIZE & & & & & & & $\begin{array}{l}0.086258 \\
(0.0014)^{* * *}\end{array}$ \\
\hline Com*SIZE & & & & & & & $\begin{array}{l}0.037432 \\
(0.0247)^{* *}\end{array}$ \\
\hline K3*SIZE & & & & & & & $\begin{array}{l}0.174126 \\
(0.0069)^{* * *}\end{array}$ \\
\hline Adj R2 & 0.398714 & 0.104841 & 0.235849 & 0.283612 & 0.437247 & 0.492456 & 0.587979 \\
\hline Prob(F-stat) & 0.000000 & 0.004877 & 0.000036 & 0.007905 & 0.000000 & 0.000001 & 0.000145 \\
\hline
\end{tabular}




\section{References}

[1] F. Kung and N. G. Rupp, "Corporate Social Responsibility and Firm Value: Recent Developments," in IntechOpen, no. Firm Value-Theory and Empirical Evidence, 2018, pp. 97-114.

[2] J. Cramer, "Corporate social responsibility: Lessons learned," Environ. Qual. Manag., vol. 13, no. 2, pp. 59-66, 2003.

[3] T. Busch and G. Friede, "The robustness of the corporate social and financial performance relation: A second-order meta-analysis," Corp. Soc. Responsib. Environ. Manag., vol. 25, no. 4, pp. 583-608, 2018.

[4] K. R. Manokaran, S. Ramakrishnan, S. S. Hishan, and K. Soehod, "The impact of corporate social responsibility on financial performance: Evidence from insurance firms," Manag. Sci. Lett., vol. 8, no. 9, pp. 913-932, 2018.

[5] T. C. T. Hou, "The relationship between corporate social responsibility and sustainable financial performance: firm-level evidence from Taiwan," Corp. Soc. Responsib. Environ. Manag., vol. 26, no. 1, pp. 19-28, 2019.

[6] A. M. Senyigit, B.Y., \& Shuaibu, "The Effect of Corporate Social Responsibility on Financial Performance of Insurance Companies in Kenya," J. Bus. Stud. Q., vol. 9, no. 1, pp. 21-31, 2017.

[7] G. Giannarakis, G. Konteos, E. Zafeiriou, and X. Partalidou, "The impact of corporate social responsibility on financial performance," Invest. Manag. Financ. Innov., vol. 13, no. 3, pp. 171-182, 2016.

[8] S. Kiran, S. J. Kakakhel, and F. Shaheen, "Corporate Social Responsibility And Firm Profitability : A Case Of Oil And Gas Sector Of Pakistan,” City Univ. Res. J. Vol. 05 Number 01, vol. 05, no. 01, pp. 110-119, 2015.

[9] N. L. L. Rahmantari, N. W. Sitiari, and I. B. A. Dharmanegara, "Effect of Corporate Social Responsibility on Company Value With Company Size and Profitability as Moderated Variables in Pharmaceutical Companies Listed on the Indonesia Stock Exchange," J. Ekon. dan Bisnis Jaadhita, vol. 6, no. 2, pp. 121-129, 2019.

[10] Y. Hu, S. Chen, Y. Shao, and S. Gao, "CSR and firm value: Evidence from China," Sustain., vol. 10, no. 12, 2018.

[11] R. C. Y. Chen and C. H. Lee, "The influence of CSR on firm value: an application of panel smooth transition regression on Taiwan," Appl. Econ., vol. 49, no. 34, pp. 34223434, 2017.

[12] N. M. Purawan and M. G. Wirakusuma, "Pengaruh Pengungkapan Corporate Social Responsibility Pada Nilai Perusahaan Dengan Kinerja Lingkungan Sebagai Pemoderasi Ngakan,” pp. 447-459, 2018.

[13] G. Moore, "Corporate social and financial performance: An investigation in the U.K. Supermarket industry,” J. Bus. Ethics, vol. 34, no. 3-4, pp. 299-315, 2001.

[14] B. Seifert, S. A. Morris, and B. R. Bartkus, "Having, Giving, and Getting: Slack Resources, Corporate Philanthropy, and Firm Financial Performance," Bus. Soc., vol. 43, no. 2, pp. 135-161, 2004.

[15] K. E. Aupperle, A. B. Carroll, and J. D. Hatfield, "an Empirical Examination of the Relationship Between Corporate Social Responsibility and Profitability.," Acad. Manag. J., vol. 28, no. 2, pp. 446-463, 1985.

[16] S. L. Holmes, "Executive perceptions of corporate social responsibility," Bus. Horiz., vol. 19 , no. 3, pp. 34-40, 1976.

[17] A. D'Amato and C. Falivena, "Corporate social responsibility and firm value: Do firm size and age matter? Empirical evidence from European listed companies," Corp. Soc. Responsib. Environ. Manag., vol. 27, no. 2, pp. 909-924, 2020.

[18] Junardi, "PENGARUH PENGUNGKAPAN CORPORATE SOCIAL," Jurkami J. Pendidik. Ekon., vol. 4, no. 2, pp. 2-13, 2019. 
[19] S. Zulfiqar, R. Sadaf, J. Popp, J. Vveinhardt, and D. Máté, “An examination of Corporate Social Responsibility and employee behavior: The case of Pakistan," Sustain., vol. 11, no. 13, pp. 1-15, 2019.

[20] Ş. C. Gherghina and G. Vintilă, "Exploring the impact of corporate social responsibility policies on firm value: The case of listed companies in Romania," Econ. Sociol., vol. 9, no. 1, pp. 23-42, 2016.

[21] C. Y. Chung, S. Jung, and J. Young, "Do CSR activities increase firm value? Evidence from the Korean market," Sustain., vol. 10, no. 9, pp. 1-22, 2018.

[22] S. J. Cho, C. Y. Chung, and J. Young, "Study on the relationship between CSR and financial performance," Sustain., vol. 11, no. 2, pp. 1-26, 2019.

[23] A. Andrikopoulos and N. Kriklani, "Environmental Disclosure and Financial Characteristics of the Firm: The Case of Denmark," Corp. Soc. Responsib. Environ. Manag., vol. 20, no. 1, pp. 55-64, 2013.

[24] M. C. Jensen and W. H. Meckling, "THEORY OF THE FIRM: MANAGERIAL BEHAVIOR, AGENCY COSTS AND OWNERSHIP STRUCTURE Michael,” $J$. financ. econ., vol. 3, pp. 305-360, 1976.

[25] M. A. Omran and D. Ramdhony, "Theoretical Perspectives on Corporate Social Responsibility Disclosure: A Critical Review," Int. J. Account. Financ. Report., vol. 5, no. 2, p. 38, 2015.

[26] V. Nikolova, "Multi-stakeholder Approach in Corporate Social Responsibility," Encycl. Corp. Soc. Responsib., vol. 3, no. 1, pp. 1731-1731, 2013.

[27] L. M. Da Silveira and M. Petrini, "Sustainable Development and Corporate Social Responsibility: A bibliometric analysis of International Scientific Production," Gest. e Prod., vol. 25, no. 1, pp. 56-67, 2018.

[28] I. A. Griselda, W. R. Murhadi, and M. Utami, "Pengaruh Corporate Social Responsibility terhadap Kinerja Perusahaan Sektor Pertambangan Terdaftar di Bursa Efek Indonesia\&Malaysia 2014-2018,” J. Entrep. Bus., vol. 1, no. 1, p. 22, 2020.

[29] J. Martin, W. Petty, and J. Wallace, "Shareholder Value Maximization - Is There a Role for Corporate Social Responsibility? by," J. Appl. Corp. Financ., vol. 21, no. 2, pp. 1-7, 2009.

[30] S. Mishra and D. Suar, Does corporate social responsibility influence firm performance of Indian companies?, vol. 95, no. 4. 2010.

[31] V. Dawar, "Article information : Agency Theory, Capital Structure and Firm Performance," Manag. Financ., vol. 40, no. 12, p. 25, 2014.

[32] H. Semuel, S. E. Hatane, C. Fransisca, J. Tarigan, and J.-M. Dautrey, “A Comparative Study on Financial Performance of the Participants in Indonesia Sustainability Reporting Awards," Indones. J. Sustain. Account. Manag., vol. 3, no. 1, p. 95, 2019.

[33] I. F. Siregar, R. Roekhudin, and L. Purwanti, "Firm Value Predictor and the Role of Corporate Social Responsibility," J. Keuang. dan Perbank., vol. 22, no. 3, pp. 475$485,2018$.

[34] H. N. Dang, V. T. T. Vu, X. T. Ngo, and H. T. V. Hoang, "Study the Impact of Growth, Firm Size, Capital Structure, and Profitability on Enterprise Value: Evidence of Enterprises in Vietnam," J. Corp. Account. Financ., vol. 30, no. 1, pp. 144-160, 2019.

[35] E. Endri and M. Fathony, "Determinants of firm's value: Evidence from financial industry,” Manag. Sci. Lett., vol. 10, no. 1, pp. 111-120, 2020.

[36] P. E. M. Murnita and I. M. P. D. Putra, "Pengaruh Corporate Social Responsibility terhadap Nilai Perusahaan dengan Profitabilitas dan Leverage Sebagai Variabel Pemoderasi," E-Jurnal Akunt., vol. 23, p. 1470, 2018.

[37] I. Irwansyah, Y. Lestari Ginting, A. Kusumawardani, and J. Erdiyanti, "Corporate Social Responsibility Disclosure, Leverage, and Firm Value: The Moderating Role of Profitability,” vol. 35, no. Miceb 2017, pp. 213-218, 2018. 
[38] R. Hanif and P. Mandasari, "The Influence of Corporate Social Responsibility to Firm Value with Profitability and Leverage as a Moderating Variable ( Studi Empiris Pada Perusahaan Manufaktur Yang Terdaftar Di Bei Tahun 2010-2012 )," J. Ekon. Univ. Riau, vol. 21, no. 04, p. 8708, 2013.

[39] S. Wuttichindanon, "Corporate social responsibility disclosure - choices of report and its determinants: Empirical evidence from firms listed on the Stock Exchange of Thailand," Kasetsart J. Soc. Sci., vol. 38, no. 2, pp. 156-162, 2017.

[40] M. C. Gupta, "the Effect of Size, Growth, and Industry on the Financial Structure of Manufacturing Companies," J. Finance, vol. 24, no. 3, pp. 517-529, 1969.

[41] H. Bowen, Social responsibilities of the businessman, Print book. New York, Harper, 1953.

[42] H. Youn, N. Hua, and S. Lee, "Does size matter? Corporate social responsibility and firm performance in the restaurant industry," Int. J. Hosp. Manag., vol. 51, pp. 127134, 2015. 